\title{
Long-term outcome of cryopreserved allograft for aortic valve replacement
}

\author{
Francesco Nappi, MD, ${ }^{\mathrm{a}}$ Antonio Nenna, MD, ${ }^{\mathrm{b}}$ Tommasangelo Petitti, MD, $\mathrm{PhD},{ }^{\mathrm{c}}$ \\ Cristiano Spadaccio, MD, PhD, ${ }^{\mathrm{d}, \mathrm{e}}$ Ivancarmine Gambardella, $\mathrm{MD},{ }^{\mathrm{f}}$ Mario Lusini, $\mathrm{MD}, \mathrm{PhD},{ }^{\mathrm{b}}$ \\ Massimo Chello, MD, ${ }^{\mathrm{b}}$ and Christophe Acar, $\mathrm{MD}^{\mathrm{g}}$
}

\section{ABSTRACT}

Objective: The most efficient surgical approach to severe aortic valve disease in the young adult is still debated: cryopreserved aortic allograft offers excellent hemodynamic and avoid anticoagulation, but long-term durability is influenced by structural valve deterioration (SVD). This study aimed to describe long-term results of aortic allografts and to identify factors influencing long-term durability.

Methods: From January 1993 to August 2010, 210 patients underwent aortic allograft replacement via the free-hand subcoronary implantation technique $(\mathrm{N}=55)$ or root replacement with coronary reimplantation $(\mathrm{N}=155)$. Clinic and echocardiographic follow-up was updated to April 2016.

Results: Overall mortality and cardiac mortality occurred in $80(38.1 \%)$ and 64 $(30.5 \%)$ patients, respectively. Reoperation was required in 69 cases $(32.8 \%)$, whereas SVD required reoperation in 57 cases $(27.1 \%)$. No early endocarditis occurred, whereas late endocarditis occurred in 4 patients. The free-hand technique seems to be associated with improved left ventricular remodeling compared with the root-replacement technique, and smaller allograft size represents a predictor of reoperation independently on the surgical technique used. In the overall population, there were 44 women of childbearing age, and 37 patients remained pregnant during the follow-up of the study. No differences were found in the clinical outcomes among women who had children and who did not.

Conclusions: Cryopreserved allograft is a valid option, especially in complex infective endocarditis and in women of childbearing age. A careful choice of allograft size and implantation technique can reduce the risk of SVD. (J Thorac Cardiovasc Surg 2018;156:1357-65)

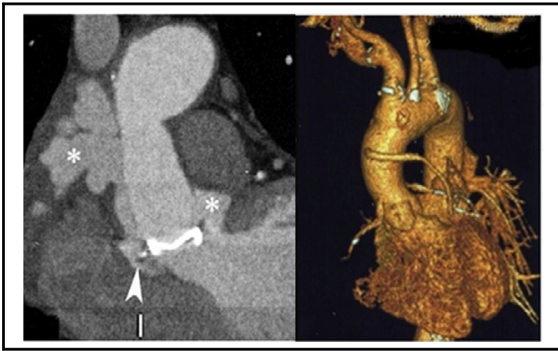

Allograft replacement for recurrent endocarditic pseudoaneurysm after Bentall procedure.

\section{Central Message}

Cryopreseved allograft is a valid option especially in infective endocarditis and during childbearing age. A careful choice of allograft size and implantation technique can reduce the risk of reoperation.

\section{Perspective}

Cryopreserved allograft (CA) showed good outcomes, acceptable durability, and low reinfection rate, representing a valid option, especially in cases of complex endocarditic destruction and during childbearing age. These aspects should be considered when weighing the procedural risks of CA implantation against its long-term benefits and when these are compared with prosthetic valves.

See Editorial Commentary page 1366

See Editorial page 1351.

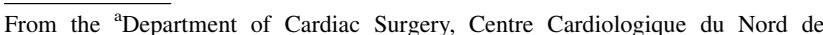
Saint-Denis, Paris, France; Departments of ${ }^{\mathrm{b}}$ Cardiovascular Surgery and ${ }^{\mathrm{c}}$ Public Health and Statistics, Università Campus Bio-Medico di Roma, Rome, Italy; ${ }^{\mathrm{d} D e p a r t m e n t}$ of Cardiothoracic Surgery, Golden Jubilee National Hospital, Glasgow, United Kingdom; ' ${ }^{\mathrm{e}}$ University of Glasgow Institute of Cardiovascular and Medical Sciences, Glasgow United Kingdom; ' Department of Cardiac Surgery, Liverpool Heart and Chest Hospital, Liverpool, United Kingdom; and ${ }^{\mathrm{g}}$ Department of Cardiac Surgery, Hopital La Pitie Salpetriere, Paris, France.

Drs Nappi and Nenna contributed equally to this article.

Received for publication April 7, 2017; revisions received Feb 12, 2018; accepted for publication April 2, 2018; available ahead of print May 11, 2018

Address for reprints: Francesco Nappi, MD, Cardiac Surgery, Centre Cardiologique du Nord de Saint-Denis, 36 Rue des Moulins Gémeaux, 93200 Saint-Denis, France (E-mail: francesconappi2@gmail.com).

$0022-5223 / \$ 36.00$

Copyright (c) 2018 by The American Association for Thoracic Surgery

https://doi.org/10.1016/j.jtcvs.2018.04.040
}

Diseases of the aortic valve raise difficult therapeutic problems in the young population. ${ }^{1}$ Currently there is no unanimous consensus on the most efficient surgical approach to severe aortic valve disease in the young adult. Moreover, even the accepted surgical dogma concerning the preference in the use of autologous or allogeneic tissues

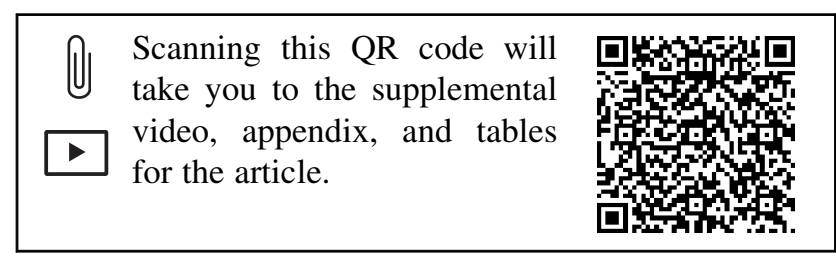




\section{Abbreviations and Acronyms}

$\mathrm{CA}=$ cryopreserved aortic allograft

NYHA $=$ New York Heart Association

SVD = structural valve deterioration

in infective conditions has been recently lively debated. ${ }^{2-4}$ Some experts have advocated the use of allograft for the lack of complications related to oral anticoagulation and the excellent quality of life permitted by the enhanced hemodynamic performance of the valves. ${ }^{5-9}$

Consensus on the use of cryopreserved aortic allograft (CA) remains firm in women with future plans of pregnancy and in pediatric cardiac surgery. Recently, initial steps in the use of decellularized allografts for aortic root replacement have been taken, with promising results. ${ }^{10,11}$ However, the actual obstacle that affects long durability of the CA is structural valve degeneration (SVD). Failure of allograft conduit and valve is approximately $30 \%$, leading frequently to reoperation. ${ }^{12,13}$ Hence, disadvantages related to the complexity of the technique of implantation, which is not normally mastered in all the centers, the restricted the availability of $\mathrm{CA}$, and the increased complexity of reoperations have limited its use.

Here, we present our series of 210 patients who have undergone aortic allograft implantation and were followed up for 20 years. We aim to describe the long-term results of this procedure in our cohort and eventually to identify factors influencing long-term durability of aortic allograft (Video 1).

\section{PATIENTS AND METHODS}

\section{Study Population and Operative Data}

The records of 210 patients (150 males) with severe aortic disease who underwent aortic allograft replacement from January 1993 to August 2010 were reviewed and all events until April 31, 2016, were analyzed. The mean

\section{Long Term Outcome of Cryopreserved Allograft for Aortic Valve Replacement}

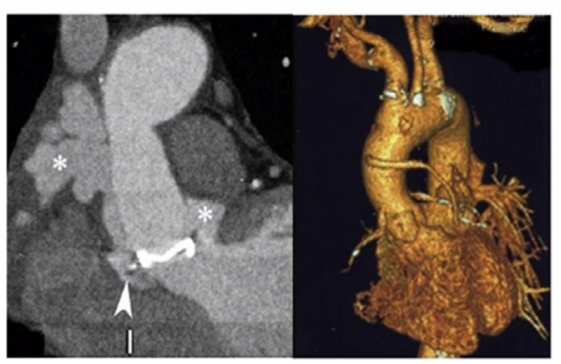

VIDEO 1. Summary of design and main findings of the study. Video available at: https://www.jtcvs.org/article/S0022-5223(18)31020-1/fulltext. age was $40.1 \pm 17.9$ years (range 10-77 years) with 10 patients younger than 18 years. Four surgeons in 2 centers were involved in these cases. Details of the clinical and operative characteristics are listed in Tables 1 and 2. Surgical strategy was based on the extent of valve lesions. The technical details of aortic allograft insertion have been widely described (APPENDIX E1), and 2 techniques have been used: the free-hand subcoronary implantation technique and the allograft root replacement with coronary reimplantation.

Valve-associated events such as SVD, cardiac death, valve-related mortality, and other outcomes are defined by Valve Academic Research Consortium-2 (VARC-2) criteria. Standard 2-dimensional and Doppler echocardiographic examinations with color-flow mapping were performed on all patients 1 week before operation. Baseline echocardiography for clinical follow-up was performed immediately after the operation at the time of discharge. Follow-up echocardiography was obtained during periodical outpatient clinics or immediately before redo surgery. All echocardiographic data were analyzed in random order by 2 independent expert cardiologists blinded with regard to the clinical data and timing of the echocardiogram (APPENDIX E1).

\section{Statistical Analysis}

Categorical variables, presented as frequencies and percentages, were compared with $\chi^{2}$ analysis or the Fisher exact test. Normality criteria were checked and met for each continuous variable, which was expressed as mean and standard deviation and compared with the Student $t$ test. KaplanMeier analyses were used to assess the probability of survival or other survival-related outcomes. For death and composite endpoints including death, a multivariable Cox regression model was used, including age, sex, etiology, type of implantation, size of the valve, and preoperative ejection fraction. For competing risk endpoint (such as SVD) with death, a competing risk framework was used and data reported as cumulative incidence.

Graphical presentation includes Kaplan-Meier curves to present crude survival probabilities in the overall population and cumulative incidence for competing risk endpoints. Longitudinal analysis was performed with a mixed-effect statistical package with random effects. Continuous (left ventricular end-diastolic diameter, left ventricular end-systolic diameter, left ventricular ejection fraction, etc) and ordinal (aortic valve regurgitation grade, New York Heart Association [NYHA] class) data were analyzed with the "meglm" package when evaluating echocardiographic parameters in the overall population (with specific tests for continuous and ordinal data), and "xtreg" or "xtologit" packages when evaluating the effect of the surgical treatment. As for Cox regression, proportional hazard assumption was tested with Schoenfeld residuals ("estat phtest" command) and was not violated in any described outcome. As for competing risk analysis, the proportionality assumption was checked with the option "tvc" after the command "stcrreg." Statistical analysis was performed with STATA Version 13 for Windows (StataCorp, College Station, Tex). A $P<.05$ was considered statistically significant.

\section{RESULTS}

Baseline characteristics and operative data of the patients are shown in Tables 1 and 2. Mean follow up was $13.0 \pm 5.6$ years, median follow-up was 13.6 (interquartile range, 9.2-17.3 years), and maximum follow up was 22.1 years. All the explants were performed at hospitals. In total, 154 patients $(73.3 \%)$ were followed up more than 10 years and 82 patients $(39.0 \%)$ more than 15 years. A total of 80 deaths (38.1\%), 64 cardiac deaths (30.5\%), and 69 reoperations $(32.8 \%)$ occurred. Echocardiographic results and details about clinical outcomes are shown in Tables E1 and E2. 
TABLE 1. Baseline characteristics

\begin{tabular}{|c|c|c|}
\hline Patients & $\mathbf{N}=\mathbf{2 1 0}$ & Percentage \\
\hline Male sex & 150 & 71.4 \\
\hline \multicolumn{3}{|l|}{ Age at implantation } \\
\hline Mean \pm SD & $40.8 \pm 18.9$ & \\
\hline Median [IQR] & $33[26-62]$ & \\
\hline Range & $10-77$ & \\
\hline Age $<40$ y & 125 & 59.5 \\
\hline Hypertension & 85 & 40.5 \\
\hline Smoking habit & 68 & 32.4 \\
\hline COPD & 29 & 13.8 \\
\hline Dyslipidemia & 35 & 16.7 \\
\hline Diabetes mellitus & 19 & 9.0 \\
\hline \multicolumn{3}{|l|}{ NYHA class } \\
\hline 1 & 0 & 0.0 \\
\hline 2 & 64 & 30.5 \\
\hline 3 & 83 & 39.5 \\
\hline 4 & 63 & 30.0 \\
\hline \multicolumn{3}{|l|}{ Etiology } \\
\hline Endocarditis & 118 & 56.2 \\
\hline Complex & 75 & 63.6 \\
\hline Noncomplex & 43 & 36.4 \\
\hline Aortomitral junction, abscess & 22 & 18.6 \\
\hline Circumferential abscess & 21 & 17.8 \\
\hline NVE & 77 & 65.2 \\
\hline PVE & 41 & 34.7 \\
\hline Staphylococcus methicillin-susceptible & 20 & 16.9 \\
\hline Staphylococcus methicillin-resistant & 23 & 19.49 \\
\hline Streptococcus viridans & 25 & 21.18 \\
\hline Other Streptococcus & 10 & 8.47 \\
\hline Enterococcus & 19 & 16.10 \\
\hline Other & 9 & 7.6 \\
\hline Negative culture & 12 & 10.66 \\
\hline Embolic events & 32 & 27.11 \\
\hline Cerebral & 25 & 21.18 \\
\hline Vegetation diameter $>10 \mathrm{~mm}$ & 57 & 48.30 \\
\hline Rheumatic & 40 & 19.0 \\
\hline Congenital & 31 & 14.7 \\
\hline Degenerative & 21 & 10.0 \\
\hline Bicuspid aortic valve & 38 & 18.1 \\
\hline \multicolumn{3}{|l|}{ Surgical indication } \\
\hline Isolated severe aortic stenosis & 46 & 21.9 \\
\hline Isolated severe aortic regurgitation & 85 & 40.5 \\
\hline Mixed aortic stenosis and regurgitation & 79 & 37.6 \\
\hline \multicolumn{3}{|l|}{ Rationale for allograft implantation } \\
\hline Age $<40$ y & 125 & 59.5 \\
\hline Woman of childbearing age & 44 & 20.9 \\
\hline Contraindication to oral anticoagulation & 86 & 40.9 \\
\hline Poor compliance to treatment & 15 & 7.1 \\
\hline Personal preference & 17 & 8.1 \\
\hline Childbearing age & 44 & 20.9 \\
\hline Bleeding disorders & 10 & 4.7 \\
\hline Endocarditis & 118 & 56.2 \\
\hline
\end{tabular}

TABLE 1. Continued

\begin{tabular}{lcc}
\hline \multicolumn{1}{c}{ Patients } & N $=\mathbf{2 1 0}$ & Percentage \\
\hline Previous cardiac surgery & 41 & 19.5 \\
Redux & 35 & 16.7 \\
Tridux & 5 & 2.4 \\
Quadridux & 1 & 0.5 \\
Previous cardiac surgery & 41 & 19.5 \\
Aortic valve replacement & 33 & 15.7 \\
Allograft & 6 & 2.8 \\
Other & 2 & 1.0 \\
Urgent surgery & 68 & 32.4 \\
\hline
\end{tabular}

$S D$, Standard deviation; $I Q R$, interquartile range; $C O P D$, chronic obstructive pulmonary disease; $N Y H A$, New York Heart Association; $N V E$, native valve endocarditis; $P V E$, prosthetic valve endocarditis.

\section{Survival}

All-cause early ( $<30$ days) mortality was $5.7 \%(\mathrm{n}=12)$. Ten of 12 patients underwent urgent surgery, and 11 of 12 patients underwent surgery due to endocarditis. Five patients died of heart failure, 4 patients died of multiorgan

TABLE 2. Operative characteristics

\begin{tabular}{|c|c|c|}
\hline Patients & $\mathbf{N}=\mathbf{2 1 0}$ & Percentage \\
\hline \multicolumn{3}{|l|}{ Surgical technique } \\
\hline Miniroot & 155 & 73.8 \\
\hline Freehand & 55 & 26.2 \\
\hline \multicolumn{3}{|l|}{ Allograft size, mm } \\
\hline 17 & 4 & \\
\hline 19 & 6 & 1.9 \\
\hline 21 & 68 & 2.8 \\
\hline 23 & 96 & 32.4 \\
\hline 25 & 33 & 45.7 \\
\hline 27 & 3 & 15.7 \\
\hline Mean size & $22.5 \pm 1.7$ & 1.4 \\
\hline Concomitant procedures & 49 & 23.3 \\
\hline Myocardial revascularization & 19 & 9.0 \\
\hline Mitral valve homograft & 10 & 4.8 \\
\hline Tricuspid valve repair & 9 & 4.3 \\
\hline Mitral homograft valve repair & 8 & 3.8 \\
\hline Tricuspid valve replacement & 3 & 1.4 \\
\hline Severe aortic annular calcification & 23 & 10.9 \\
\hline Cardiopulmonary bypass, min & $230 \pm 82$ & \\
\hline Aortic crossclamp time, min & $185 \pm 71$ & \\
\hline \multicolumn{3}{|l|}{ Donor } \\
\hline Age, mean $\pm \mathrm{SD}$ & $44.1 \pm 7.1$ & \\
\hline Age, range & $5-61$ & \\
\hline Age $>50 y$ & 68 & \\
\hline Annulus, mean $\pm \mathrm{SD}$ & $25.2 \pm 3.6$ & 32.3 \\
\hline Sex mismatch & 92 & 43.8 \\
\hline Annular size mismatch $(>5 \mathrm{~mm})$ & 11 & 5.2 \\
\hline Blood group mismatch & 109 & 51.9 \\
\hline $\mathrm{Rh}$ antigen mismatch & 34 & 16.2 \\
\hline
\end{tabular}


TABLE 3. Summary of adverse outcomes

\begin{tabular}{lc}
\hline & No. patients \\
\hline Patients & 210 \\
Overall mortality & 80 \\
\hline Early mortality (<30 d or in-hospital death) & 12 \\
$\quad$ Urgent surgery & 10 \\
Endocarditis ( $\mathrm{n}=118 / 210)$ & 11 \\
Miniroot technique & 11 \\
\hline Late mortality & 68 \\
Valve-related mortality and morbidity & \\
Reoperation & 12 \\
Urgent surgery* & 9 \\
Structural valve degeneration $\dagger$ & 14 \\
Reinfection & 4 \\
Thromboembolism & 3 \\
Anticoagulant-related hemorrhage & 3 \\
Composite valve-related mortality & 36 \\
and morbidity (valve-related events) & \\
\hline Nonvalve-related events & 22 \\
Heart failure & 16 \\
Sudden cardiac death & 6 \\
Noncardiac mortality & 10 \\
Malignancies & 6 \\
Respiratory failure & 3 \\
Renal failure & 1 \\
\hline
\end{tabular}

Follow-up duration: max: 22.1 years; mean: $13.0 \pm 5.6$ years; time at risk: 2731.7 allograft-years. *Nine of 12 patients underwent urgent surgery. $†$ Twelve patients were not reoperated, 6 died before intervention, and 6 refused surgical treatment.

failure, and 3 patients died of acute respiratory distress syndrome, respectively (Table 3, Figure 1, A). All-cause late ( $>30$ days) mortality occurred in 80 patients, with 64 cardiac deaths, 16 noncardiac deaths, and valve-related mortality in 18 patients (Table 4). Survival from cardiac related events is shown in Figure 1, $B$, and Table 4.

\section{Reoperation}

Eighty-one patients had aortic allograft failure, and 69 of these revealed SVD (Table 4). Table 5 summarizes the specifics of the explanted allografts and the details of the 69 reoperations. Freedom from reoperation on the allograft conduit is displayed in Figure 1, C. Reoperation-related mortality was $15 \%$ for both first-time and multiple-time redo-procedure, and 9 of 12 patients underwent urgent surgery. This high rate of mortality was related to hostile calcification of the root and endocarditis recurrence (4 patients) after multiple repeat surgery. Nine SVDreoperations had late mortality, and 48 SVD reoperations are still in follow up. Expected valve durability (median survival time without reoperation) is 17.7 years.

\section{Major Adverse Cardiac and Cerebrovascular Events}

Overall freedom from major adverse cardiac and cerebrovascular events (all valve-related mortality; valve- related morbidity: structural and nonstructural valve dysfunction with the need of reoperation, thrombosis, bleeding, embolism, neurologic events, endocarditis, rehospitalization for heart failure, and worsening NYHA class) is shown in Table 4 and Figure 1, D.

\section{Infective Endocarditis}

No early endocarditis occurred. Late endocarditis occurred in 4 patients (freedom from endocarditis at 20 years: $98.1 \% \pm 1.5 \%$ ). Overall, 4 allograft reoperations referable to endocarditis were performed.

\section{Thrombosis and Bleeding}

Allograft-related thrombotic and thromboembolic events occurred in 3 patients. Major internal or external bleeding was revealed in 1 patient. A total of 3 patients skilled the composite end point of thrombosis, embolism, or bleeding (freedom from thrombosis and bleeding at 20 years: $98.6 \% \pm 1.4 \%)$.

\section{Structural Valve Degeneration}

SVD required reoperation in 57 patients (Table 4). Twelve patients did not undergo reoperation, 6 died before intervention, and 6 refused surgical treatment. Twelve interventions were performed for nonstructural valve deterioration, of these 4 patients required reoperation for late endocarditis. Cumulative incidence of SVD at 10, 15, and 20 years was $0.6 \% \pm 0.6 \%, 3.2 \% \pm 1.6 \%$, and $57.0 \% \pm 6.6 \%$, respectively (Figure 2).

SVD was revealed with leaflet tear of the right cusp in 26 patients and of the left cusp in 24 patients. In total 19 patients experienced a tear of both cusps. All patients had severe clinical presentation of severe dyspnea related to severe regurgitation. In 23 patients, aortic stenosis was associated. Usually, the time between SVD and the appearance of symptoms ranged from less than 1 months to 3 months, and reoperation was required within the same period. Fifty-six patients manifested chronic symptoms and required reoperation after 3 months. No significant difference was found in the position of tear with regard to the surgical procedure ( $P=.264$, Table E3). Generally, the location of tears was at the base of allograft or in the proximity of the commissures. Macroscopic calcifications were observed in younger patients who developed an early structural valve degeneration with severe aortic regurgitation caused by leaflet tear. In patients with severe stenosis allograft leaflet were severely calcified.

\section{Quality of Life}

Functional status as evaluated by NYHA class showed a statistical significant improvement both postoperatively and in the long-term in comparison with the baseline conditions. This improvement was stable over the course of the study, and very few patients experienced a worsening of 

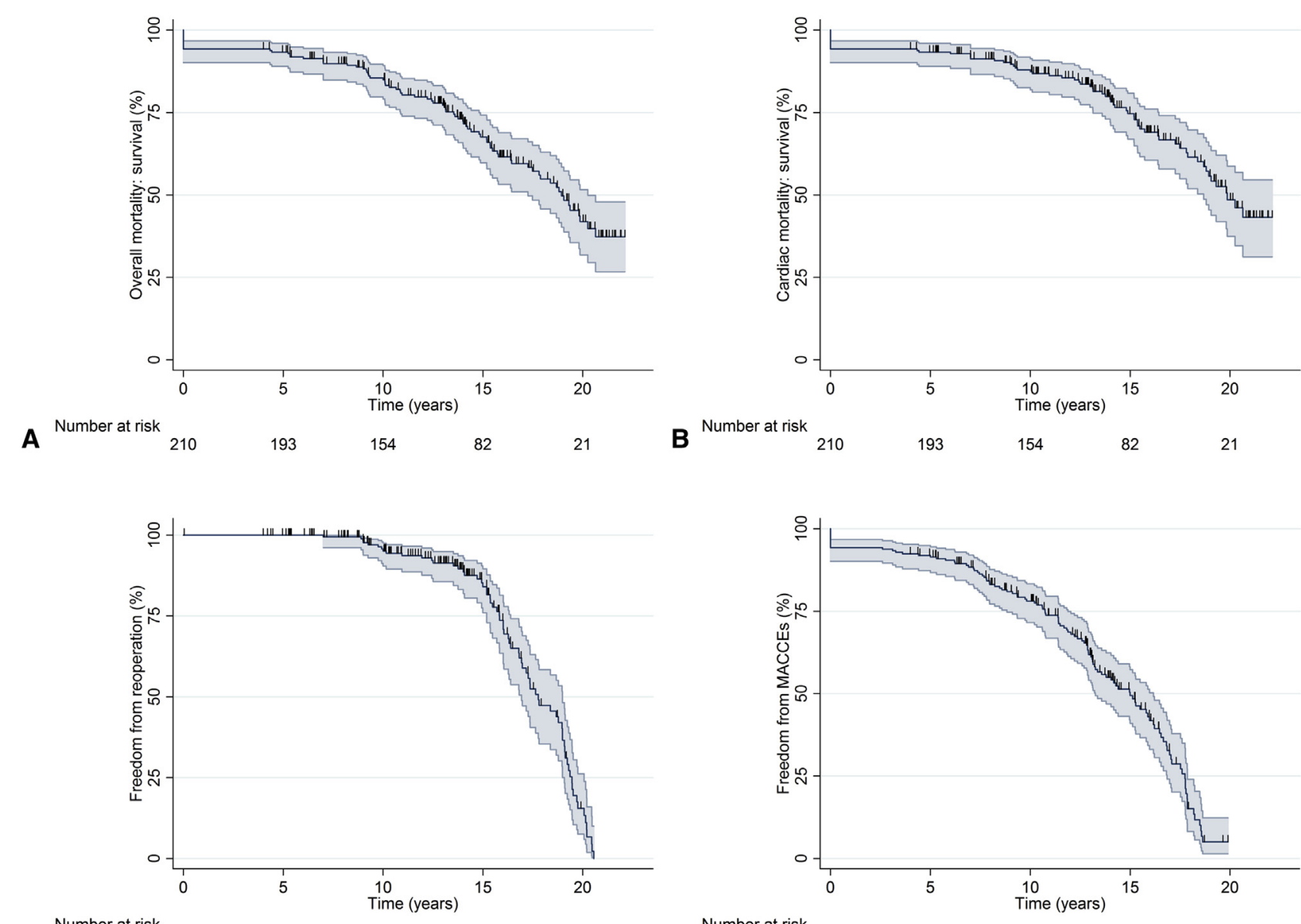

C

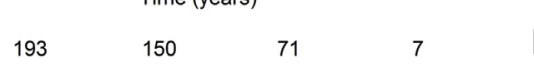

D Number at risk 210

189

137

0

FIGURE 1. Kaplan-Meier analysis. A, Overall survival; B, survival from cardiac-related events; C, freedom from reoperation; D, and freedom from MACEs. MACCEs, Major adverse cardiac and cerebrovascular events.

NYHA class or rehospitalization for heart failure during follow-up (Supplementary Materials).

\section{Outcomes in Childbearing Age}

In the overall population, there were $44(21 \%)$ women of childbearing age. Among those, $37(84.1 \%)$ patients remained pregnant during the follow-up of the study and gave birth to at least 1 or more healthy children. We found no statistical significant difference in the clinical outcomes among women who had children and who did not (Table E4).

\section{Regression Analysis}

Cox regression showed that overall mortality and cardiac mortality were not influenced by allograft implantation technique or valve size. Notably, a greater valve size was associated with a reduced risk of reoperation (hazard ratio $0.79, P=.012$ ) (Table E5).

The longitudinal analysis of echocardiographic data showed that freehand technique might turn into a better remodeling of the left ventricle (with decreased left ventricular end-diastolic diameter, decreased left ventricular end-systolic diameter, and improved left ventricular ejection fraction) with reduced NYHA class compared with the miniroot technique. However, the freehand technique tends to increase gradients through the aortic valve (Table E6).

\section{DISCUSSION}

The main findings of this study are that (1) CA is still a valid option in aortic valve replacement, especially in cases of annular and periannular tissue destruction, providing acceptable durability and clinical outcomes with optimal hemodynamic performance; (2) reoperation is rare in the first years after implantation and tends to be required for SVD after more than 15 years after surgery; (3) the long-term incidence of endocarditis after allograft implantation is low; (4) the miniroot technique seems to be associated with detrimental left ventricular remodeling compared with the freehand technique; (5) small allograft size represents a predictor of reoperation independently on the surgical technique used; and (6) women with future plans of pregnancy might benefit from allograft 
TABLE 4. Clinical outcomes

\begin{tabular}{|c|c|c|c|c|c|c|c|c|}
\hline & $\begin{array}{c}\text { Event, } \mathbf{n} \\
(\%)\end{array}$ & $\begin{array}{c}\text { Freedom from } \\
\text { event at } 1 \mathrm{y}\end{array}$ & $\begin{array}{l}\text { Freedom from } \\
\text { event at } 5 \text { y }\end{array}$ & $\begin{array}{l}\text { Freedom from } \\
\text { event at } 10 \mathrm{y}\end{array}$ & $\begin{array}{l}\text { Freedom from } \\
\text { event at } 15 y\end{array}$ & $\begin{array}{c}\text { Freedom from } \\
\text { event at } 20 y\end{array}$ & $\begin{array}{c}\text { MST, } \\
\mathbf{y}\end{array}$ & $\begin{array}{c}\text { AUC, } \\
\mathbf{y}\end{array}$ \\
\hline $\begin{array}{l}\text { Overall } \\
\text { mortality }\end{array}$ & $80(38.1)$ & $\begin{array}{l}94.3 \pm 1.6 \\
\quad(90.2-96.7)\end{array}$ & $\begin{array}{r}93.3 \pm 1.7 \\
\quad(88.9-95.9)\end{array}$ & $\begin{array}{l}85.5 \pm 2.5 \\
\quad(79.7-89.7)\end{array}$ & $\begin{array}{r}61.3 \pm 40.4 \\
\quad(52.9-68.7)\end{array}$ & $\begin{array}{l}41.8 \pm 5.1 \\
\quad(31.7-51.5)\end{array}$ & 18.9 & 16.7 \\
\hline $\begin{array}{l}\text { Cardiac } \\
\text { mortality }\end{array}$ & $64(30.5)$ & $\begin{array}{l}94.3 \pm 1.6 \\
\quad(90.2-96.7)\end{array}$ & $\begin{array}{l}93.3 \pm 1.7 \\
\quad(88.9-95.9)\end{array}$ & $\begin{array}{l}87.9 \pm 2.3 \\
\quad(82.5-91.7)\end{array}$ & $\begin{array}{l}97.6 \pm 3.5 \\
\quad(66.9-80.8)\end{array}$ & $\begin{array}{l}48.4 \pm 5.5 \\
\quad(37.4-58.6)\end{array}$ & 19.8 & 17.5 \\
\hline MACCEs & $115(54.7)$ & $\begin{array}{l}94.3 \pm 1.6 \\
\quad(90.2-96.7)\end{array}$ & $\begin{array}{l}91.8 \pm 1.9 \\
\quad(87.2-94.9)\end{array}$ & $\begin{array}{l}78.1 \pm 3.0 \\
\quad(71.6-83.3)\end{array}$ & $\begin{array}{l}50.6 \pm 4.1 \\
\quad(42.3-58.4)\end{array}$ & $\begin{array}{l}4.6 \pm 2.7 \\
\quad(1.1-12.0)\end{array}$ & 15.0 & 13.4 \\
\hline Reoperation & $69(32.8)$ & $100.0 \pm 0.0$ & $100.0 \pm 0.0$ & $\begin{array}{l}95.7 \pm 1.6 \\
\quad(91.3-97.9)\end{array}$ & $\begin{array}{l}84.3 \pm 3.3 \\
\quad(76.4-89.8)\end{array}$ & $\begin{array}{l}15.5 \pm 4.8 \\
\quad(7.5-26.3)\end{array}$ & 17.7 & 17.2 \\
\hline \multirow{2}{*}{$\begin{array}{l}\text { Reoperation, } \\
\text { SVD-related } \\
\text { only }\end{array}$} & $57(27.1)$ & $100.0 \pm 0.0$ & $100.0 \pm 0.0$ & $96.9 \pm 1.3$ & $89.4 \pm 2.9$ & $19.1 \pm 5.8$ & 19.0 & 17.8 \\
\hline & $\begin{array}{l}\text { Event, } \\
\text { n }(\%)\end{array}$ & $\begin{array}{c}\text { Cumulative } \\
\text { incidence } \\
\text { at } \mathbf{1 y}\end{array}$ & $\begin{array}{l}\text { Cumulative } \\
\text { incidence } \\
\text { at } 5 y\end{array}$ & $\begin{array}{c}\text { Cumulative } \\
\text { incidence } \\
\text { at } 10 \mathrm{y}\end{array}$ & $\begin{array}{l}\text { Cumulative } \\
\text { incidence } \\
\text { at } 15 \mathrm{y}\end{array}$ & $\begin{array}{l}\text { Cumulative } \\
\text { incidence } \\
\text { at } 20 \mathrm{y}\end{array}$ & & \\
\hline SVD & $57(27.1)$ & 0 & 0 & $\begin{array}{r}0.6 \pm 0.6 \\
(0.1-4.1)\end{array}$ & $\begin{array}{r}3.2 \pm 1.6 \\
(1.2-8.4)\end{array}$ & $\begin{array}{c}57.0 \pm 6.6 \\
(44.7-70.1)\end{array}$ & & \\
\hline
\end{tabular}

Survival probability was calculated via Kaplan-Meier estimates. Results are shown as mean \pm standard error of the mean (95\% confidence interval). When the survival curve does not cross the $50 \%$ line, the MST is not applicable. MST, Median survival time, in years; AUC, area under the Kaplan-Meier curve, in years; $M A C C E s$, major adverse cardiac and cerebrovascular events: all valve-related mortality; valve-related morbidity: structural and nonstructural valve dysfunction with the need of reoperation, thrombosis, bleeding, embolism, neurologic events, endocarditis, rehospitalization for heart failure, and worsening New York Heart Association class; SVD, structural valve degeneration.

implantation, as the long-term clinical outcomes are not different from the rest of the population.

\section{Survival in the Overall Population}

In the majority of case-series studies addressing the survival of $\mathrm{CA}$, encouraging results have been published. In the series reported by Fukushima and colleagues, ${ }^{8}$ median survival was 11 years if age was 0 to 19 years at implantation, 24 years for those aged 20 to 39 years, 22 years for those aged 40 to 59 years, and 14 years for those aged 60 to 81 years. Arabkhani and colleagues ${ }^{5}$ showed an 8 -year

TABLE 5. Details of explanted allografts

\begin{tabular}{|c|c|}
\hline Overall explanted & $\mathbf{N}=\mathbf{8 1}$ \\
\hline SVD & 69 \\
\hline SVD, nonreoperations & 12 \\
\hline SVD, reoperations & 57 \\
\hline NSVD & 12 \\
\hline Endocarditis & 4 \\
\hline Cusp retraction & 3 \\
\hline Pseudoaneurysm & 2 \\
\hline Fibrosis & 2 \\
\hline Right coronary ostia malposition* & 1 \\
\hline \multicolumn{2}{|c|}{$\begin{array}{l}\text { A total of } 44 \text { of } 81 \text { patients }(54.3 \%) \text { had miniroot technique at the first surgery. Nine } \\
\text { SVD reoperations had late mortality: } 48 \text { SVD reoperations are still in follow-up. Of } \\
\text { the } 69 \text { reoperations: AVR mechanical } 34(49.3 \%) \text {, AVR biological } 7(10.1 \%) \text {, } \\
\text { homograft } 10(14.5 \%) \text {, Bentall } 16(23.2 \%) \text {, ascending aorta } 2(2.9 \%) \text {. SVD, } \\
\text { Structural valve degeneration; NSVD, nonstructural valve disease. *Patient was } \\
\text { reoperated and underwent a Cabrol-type coronary ostia reimplantation. }\end{array}$} \\
\hline
\end{tabular}

actuarial survival of $77.6 \%$, and in a recent large series followed-up to 20 years cumulative survival was $41 \%$. We reported similar data to the actuarial survival, with $93.3 \% \pm 1.7 \%$ at 5 years and $67.6 \% \pm 3.7 \%$ at 15 years and $41.8 \pm 5.1$ at 20 years. After we excluded the early mortality, mainly attributable to intraoperative complications or difficulties related to the endocarditis indication usually characterizing CA use, the overall survival was not significantly different than mechanical valves, as testified by a large study by Chiang and colleagues ${ }^{14}$ in JAMA (actuarial 15-year survival was 60.6\%) and biological valves (actuarial 15-year survival $62.1 \%$ ). These results are in line with the reports on long-term follow-up of Carpentier-

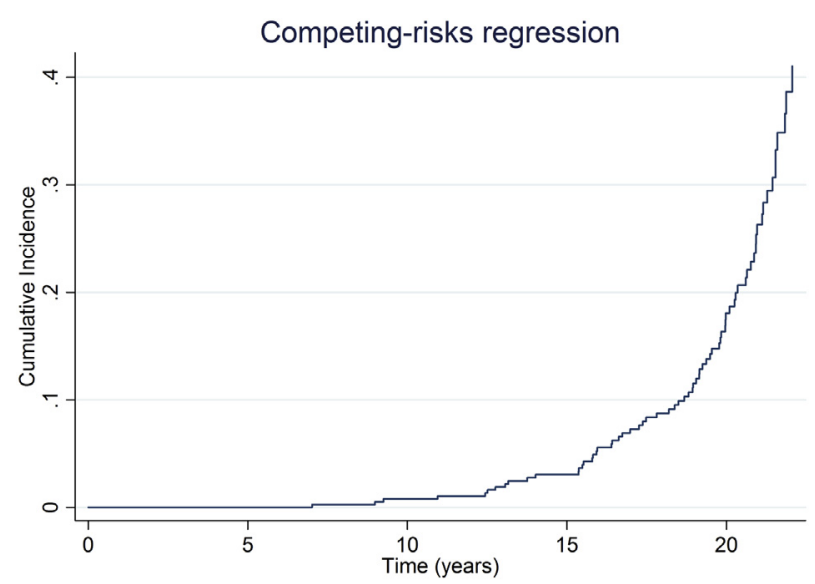

FIGURE 2. Cumulative incidence of structural valve generation. 
Edwards bioprosthesis (15 years survival $65.6 \%){ }^{15}$ with particular benefit in patients aged older than 60 years. ${ }^{15,16}$ In contrast, stentless valves implanted in subcoronary position have shown poorer results at 15 years' follow-up (survival 35\%). ${ }^{17}$

These outcomes are particularly interesting, considering the need to weigh the results against the indications and the type of bioprosthesis used. Indeed, in contrast with bioprosthesis, the vast majority of allografts are used in critical conditions after failure of previous valve interventions with a significant increase in the surgical risk. Furthermore, differences among the type of prosthesis used (ie, mechanical vs biological) ${ }^{18}$ or the composition of bioprostheses $^{19}$ might have a profound influence in determining the long-term outcomes of these patients. In this context, patients implanted with prosthetic valves are also more prone to reinfection, with aggressive prostheses lesions and need for reintervention.

The high reoperation-related mortality in this series was dictated by reinfection, which implies wide destructive surgery, and extensive calcification of the allograft. Also, these figures might be explained by the fact that study has been conducted in the presutureless technology era, which is a viable option to circumvent this issue, particularly in the younger population $^{20,21}$ and also in case of homograft reinfection, ${ }^{22}$ whereas transcatheter aortic valve replacement might be safely applied in noninfected calcified SVD with reduced mortality and morbidity. ${ }^{4,23}$

However daunting the procedural aspects of CA implantation, reoperation and reinfection rates are lower than prosthetic valve replacement, and this aspect needs to be considered when weighting the procedural risks of CA implantation against its long-term benefits ${ }^{24,25}$ and when comparing those with the natural history of a biological or mechanical valve and the mortality associated to reoperation for prosthetic valve endocarditis. ${ }^{4,26}$ Lastly, $\mathrm{CA}$ provides an enormous advantage in annular and periannular tissue destruction, for which allograft should be the primary indication. ${ }^{4}$ This is not related to the reinfection burden but rather to the fact that the $\mathrm{CA}$ has a curtain of perivalvular tissue that can be used to reconstruct the periannular structures.

\section{Allograft Valve Replacement in Endocarditis}

The estimates of aortic valve endocarditis with the need for operation are reported in $0.15 \% /$ patient-years. We advocate the use of autologous allogenic tissue in cases involving prosthetic valves and in complex and aggressive lesions, such as circumferential abscess formation or mitro-aortic junction extension. Indeed, despite in the past few years the use of stented xenograft and mechanical prostheses has greatly exceeded the use of allogenic tissues due to ease of implantation and scarce availability of CA, several reports have established the superiority of autologous allogenic tissues in these circumstances. ${ }^{4,27-29}$ In our study, we showed low risk of reinfection independent of the implant technique used. Interestingly, there was no significant difference in 30-day mortality or during the follow-up among the endocarditis versus nonendocarditis group. The observed 30-day rate of death (1.9\% in the endocarditis group and $3.8 \%$ in nonendocarditis group) was greater in urgent conditions, in elderly patients, and in prosthetic valve endocarditis. These data are comparable with the national rates reported by the American College of Cardiology/American Heart Association and the Society of Thoracic Surgeons for mechanical or biological valves. ${ }^{30}$

However, our findings are in contrast with the recently reported outcomes by $\mathrm{Kim}$ and colleagues ${ }^{2}$ in a propensity-matched analysis comparing allografts, xenografts, and mechanical prostheses in the setting of infective endocarditis, which showed no demonstrable benefit in terms of mortality and resistance to reinfection in the allograft group. Our study confirmed a low rate of recurrent endocarditis among patients undergoing aortic allograft valve replacement, which is in contrast with the results by Kim and colleagues. ${ }^{2}$ Conversely, our findings are similar to those reported in previous systematic reviews, ${ }^{31}$ and the evidence that the risk of recurrence of endocarditis is also related to predisposing factors unrelated to the valve type, such as diabetes mellitus, corticosteroid therapy, poor dental care, and blood product usage, might additionally support the use of the allogenic tissues in patients with infective endocarditis. ${ }^{32}$

\section{Reoperations on Allograft for Structural and Nonstructural Valve Deterioration}

The estimates of structural and nonstructural allograft deterioration with the need for reoperation in young patients is reported to range between $2.47 \%$ and $3.83 \%$ per patient-year, with a pooled mean of $3.08 \%$ per patient-year. ${ }^{8}$ In contrast, in the present series reoperations on the allograft are common between 10 and 20 years from surgery with a freedom from reoperation of $95.7 \% \pm 1.6 \%$ at 10 years, $84.3 \% \pm 3.3 \%$ at 15 years, and $15.5 \% \pm 4.8 \%$ at 20 years, respectively. This is in accordance with the data of the series reported by Takkenberg and colleagues ${ }^{6}$ at 15 years. Aortic regurgitation was the leading cause of reoperation based on structural valve failure with root calcification; other indications were related to nonstructural valve deterioration or infective endocarditis. In population older than 40 years, the linearized estimates of structural and nonstructural allograft conduit deterioration with the need for reoperation have been shown to range between $0.7 \%$ and $1.7 \%$ and $0.05 \%$ and $0.32 \%$ per patient-year, respectively.

In our series, SVD was related to leaflet tear in all cases, with consequent valve failure. The wear-and-tear 
phenomenon has been attributed to a combination of hemodynamic and rheological disturbances and biomechanical stress on the leaflets, which lead to the formation and accumulation of calcium aggregates, as reported by several studies analyzing the mechanisms of failure of stentless valves. ${ }^{17,33,34}$ Although the relative contribution of these factors remains debated, the implant technique might play an important role in this context as imparting different degrees of mechanical stress at the level of the root complex dependently on the subcoronary or miniroot insertion..$^{35,36}$ The wear-and-tear phenomenon was prevalently noticed in right and left cusp exposed to overpressure, whereas the noncoronary sinus appeared more protected. It might be speculated that the difficult geometric adjustment of the allograft during the implantation may determine an inhomogeneous mechanical stress on right and left suture line, which favors premature degeneration of the respective cusps, leading to leaflet dysfunction. The preferential localization of the tears in over pressurized areas might also allow us to hypothesize that reduced elastomechanical compliance of the degenerated and calcified allograft roots play a role in this context. From the clinical perspective, the short interval between the clinical presentation and the need for reoperation reinforce the idea of a rapid transition from a normally functioning valve to severe valve regurgitation induced by leaflet tear.

\section{SVD and Pregnancy}

To our knowledge, no other study has reported outcomes of allograft in childbearing age. In this series, $84 \%$ of the women of childbearing age gave birth to 1 or more babies, and we found no differences in the clinical outcomes in these women with respect to the rest of the women who underwent surgery. Interestingly, there was no association between the number of subsequent pregnancies and the risk of allograft degeneration, supporting the idea that elevated endogenous estro-progestinic levels do not play a significant role in SVD. Aortic allograft, avoiding anticoagulation, might constitute an additional advantage for this subcategory as allowing the patient to conduct a normal life after the operation. ${ }^{37}$ These findings might be useful in patient counseling and during the heart team discussion regarding the best treatment option in this subset of patients with severe aortic valve disease.

\section{Limitations}

The authors acknowledge that one of the main limitations of this study is its retrospective inner nature, which might still carry a significant bias. However, common limitations might be mitigated by the fact that no missing data were present in our database and both echocardiographic evaluations and reoperations were performed in our centers.

\section{CONCLUSIONS}

This study reported the very long-term outcomes of CA in aortic position in 2 high-volume centers. CA represents a valid option, especially in the context of infective endocarditis and in a specific subset of patients, such as women of childbearing age. Long-term SVD is a considerable concern, but careful choice of allograft size and implantation technique might minimize this risk.

\section{Conflict of Interest Statement}

Authors have nothing to disclose with regard to commercial support.

\section{References}

1. Mazine A, David TE, Rao V, Hickey EJ, Christie S, Manlhiot C, et al. Long-term outcomes of the Ross procedure versus mechanical aortic valve replacement: propensity-matched cohort study. Circulation. 2016;134:576-85.

2. Kim JB, Ejiofor JI, Yammine M, Camuso JM, Walsh CW, Ando M, et al. Are homografts superior to conventional prosthetic valves in the setting of infective endocarditis involving the aortic valve? J Thorac Cardiovasc Surg. 2016;151:1239-48.e1232.

3. Kirklin JK. Challenging homografts as the holy grail for aortic valve endocarditis. J Thorac Cardiovasc Surg. 2016;151:1230-1.

4. Nappi F, Spadaccio C, Acar C. Use of allogeneic tissue to treat infective valvular disease: has everything been said? J Thorac Cardiovasc Surg. 2017; $153: 824-8$

5. Arabkhani B, Bekkers JA, Andrinopoulou ER, Roos-Hesselink JW, Takkenberg JJ, Bogers AJ. Allografts in aortic position: insights from a 27-year, single-center prospective study. J Thorac Cardiovasc Surg. 2016;152: 1572-9.e1573.

6. Takkenberg JJ, van Herwerden LA, Eijkemans MJ, Bekkers JA, Bogers AJ. Evolution of allograft aortic valve replacement over 13 years: results of 275 procedures. Eur J Cardiothorac Surg. 2002;21:683-91; discussion 691.

7. El-Hamamsy I, Clark L, Stevens LM, Sarang Z, Melina G, Takkenberg JJ, et al. Late outcomes following freestyle versus homograft aortic root replacement: results from a prospective randomized trial. J Am Coll Cardiol. 2010;55:368-76.

8. Fukushima S, Tesar PJ, Pearse B, Jalali H, Sparks L, Fraser JF, et al. Long-term clinical outcomes after aortic valve replacement using cryopreserved aortic allograft. J Thorac Cardiovasc Surg. 2014;148:65-72.e62.

9. Smedira NG, Blackstone EH, Roselli EE, Laffey CC, Cosgrove DM. Are allografts the biologic valve of choice for aortic valve replacement in nonelderly patients? Comparison of explantation for structural valve deterioration of allograft and pericardial prostheses. J Thorac Cardiovasc Surg. 2006;131: 558-64.e554.

10. da Costa FD, Costa AC, Prestes R, Domanski AC, Balbi EM, Ferreira AD, et al. The early and midterm function of decellularized aortic valve allografts. Ann Thorac Surg. 2010;90:1854-60.

11. Helder MR, Kouchoukos NT, Zehr K, Dearani JA, Maleszewski JJ, Leduc C, et al. Late durability of decellularized allografts for aortic valve replacement: a word of caution. J Thorac Cardiovasc Surg. 2016;152:1197-9.

12. Musci M, Weng Y, Hübler M, Amiri A, Pasic M, Kosky S, et al. Homograft aortic root replacement in native or prosthetic active infective endocarditis: twenty-year single-center experience. J Thorac Cardiovasc Surg. 2010;139:665-73.

13. David TE. Reoperations after the Ross procedure. Circulation. 2010;122: 1139-40.

14. Chiang YP, Chikwe J, Moskowitz AJ, Itagaki S, Adams DH, Egorova NN Survival and long-term outcomes following bioprosthetic vs mechanical aortic valve replacement in patients aged 50 to 69 years. JAMA. 2014;312:1323-9.

15. Bourguignon T, El Khoury R, Candolfi P, Loardi C, Mirza A, BoulangerLothion J, et al. Very long-term outcomes of the Carpentier-Edwards Perimount aortic valve in patients aged 60 or younger. Ann Thorac Surg. 2015;100:853-9.

16. Bourguignon T, Bouquiaux-Stablo AL, Candolfi P, Mirza A, Loardi C, May MA, et al. Very long-term outcomes of the Carpentier-Edwards Perimount valve in aortic position. Ann Thorac Surg. 2015;99:831-7.

17. Mohammadi S, Tchana-Sato V, Kalavrouziotis D, Voisine P, Doyle D, Baillot R, et al. Long-term clinical and echocardiographic follow-up of the Freestyle stentless aortic bioprosthesis. Circulation. 2012;126(11 suppl 1):S198-204. 
18. Glaser N, Jackson V, Holzmann MJ, Franco-Cereceda A, Sartipy U. Aortic valve replacement with mechanical vs. biological prostheses in patients aged 50-69 years. Eur Heart J. 2016;37:2658-67.

19. Chan V, Kulik A, Tran A, Hendry P, Masters R, Mesana TG, et al. Long-term clinical and hemodynamic performance of the Hancock II versus the Perimount aortic bioprostheses. Circulation. 2010;122(11 suppl):S10-6.

20. Folliguet TA, Laborde F. Sutureless Perceval aortic valve replacement in aortic homograft. Ann Thorac Surg. 2013;96:1866-8.

21. Folesani G, Calcara G, Minniti G, Polesel E. Reoperation for aortic homograft failure using an Edwards Intuity valve. Interact Cardiovasc Thorac Surg. 2016;22:378-80.

22. Gupta P, McCormack DJ, Szczeklik M, Ambekar S, Lall KS. Infected calcified homograft root: a sutureless solution. Ann Thorac Surg. 2013;95:1789-91.

23. Dainese L, Fusari M, Trabattoni P, Biglioli P. Redo in aortic homograft replacement: transcatheter aortic valve as a valid alternative to surgical replacement. J Thorac Cardiovasc Surg. 2010;139:1656-7.

24. Kowert A, Vogt F, Beiras-Fernandez A, Reichart B, Kilian E. Outcome after homograft redo operation in aortic position. Eur J Cardiothorac Surg. 2012; 41:404-8.

25. Joudinaud TM, Baron F, Raffoul R, Pagis B, Vergnat M, Parisot C, et al. Redo aortic root surgery for failure of an aortic homograft is a major technical challenge. Eur J Cardiothorac Surg. 2008;33:989-94.

26. Grubitzsch H, Christ T, Melzer C, Kastrup M, Treskatsch S, Konertz W. Surgery for prosthetic valve endocarditis: associations between morbidity, mortality and costs. Interact Cardiovasc Thorac Surg. 2016;22:784-91.

27. Nappi F. CRT-721 The cryopreserved mitral homograft valve: 19 years experience. JACC Cardiovasc Interv. 2014;7:S58.

28. Olivito S, Lalande S, Nappi F, Hammoudi N, D'Alessandro C, Fouret P, et al. Structural deterioration of the cryopreserved mitral homograft valve. J Thorac Cardiovasc Surg. 2012;144:313-20. 320.e311.

29. d'Alessandro C, Vaquette B, Acar C. Recurrent aortic pseudoaneurysm following David and Bentall operations treated by homograft replacement. J Heart Valve Dis. 2010;19:152-3.
30. Brennan JM, Edwards FH, Zhao Y, O'Brien SM, Douglas PS, Peterson ED, et al Long-term survival after aortic valve replacement among high-risk elderly patients in the United States: insights from the Society of Thoracic Surgeons adult cardiac surgery database, 1991 to 2007. Circulation. 2012;126:1621-9.

31. Huygens SA, Mokhles MM, Hanif M, Bekkers JA, Bogers AJ, Rutten-van Mölken MP, et al. Contemporary outcomes after surgical aortic valve replacement with bioprostheses and allografts: a systematic review and meta-analysis. Eur J Cardiothorac Surg. 2016;50:605-16.

32. Alkhawam H, Sogomonian R, Zaiem F, Vyas N, El-Hunjul M, Jolly J, et al Morbidity and mortality of infective endocarditis in a hospital system in New York City serving a diverse urban population. J Investig Med. 2016;64: 1118-23.

33. David TE, Feindel CM, Bos J, Ivanov J, Armstrong S. Aortic valve replacemen with Toronto SPV bioprosthesis: optimal patient survival but suboptimal valve durability. J Thorac Cardiovasc Surg. 2008;135:19-24.

34. Kobayashi J. Stentless aortic valve replacement: an update. Vasc Health Risk Manag. 2011;7:345-51.

35. Takkenberg JJ, Klieverik LM, Bekkers JA, Kappetein AP, Roos JW Eijkemans MJ, et al. Allografts for aortic valve or root replacement: insights from an 18-year single-center prospective follow-up study. Eur J Cardiothorac Surg. 2007;31:851-9.

36. Willems TP, Takkenberg JJ, Steyerberg EW, Kleyburg-Linkers VE, Roelandt JR, Bos E, et al. Human tissue valves in aortic position: determinants of reoperation and valve regurgitation. Circulation. 2001;103:1515-21.

37. Arabkhani B, Heuvelman HJ, Bogers AJ, Mokhles MM, Roos-Hesselink JW, Takkenberg JJ. Does pregnancy influence the durability of human aortic valve substitutes? J Am Coll Cardiol. 2012;60:1991-2.

Key Words: cryopreserved aortic allograft, aortic valve replacement, endocarditis, long-term, allograft, structural valve degeneration

Readers who found these articles interesting may also like to read the following papers found in recent and future issues of our sister publications, Seminars in Thoracic and Cardiovascular Surgery and Operative Techniques in Thoracic and Cardiovascular Surgery!

\section{Adult: Aortic Valve}

ORIGINAL SUBMISSION: Single Dose Del Nido Cardioplegia in Minimally Invasive Aortic Valve Surgery. Daniel Ziazadeh. Semin Thoracic Surg 2017: 471-476

Editorial Commentary: Is “As Good” Good Enough? James I. Fann. Semin Thoracic Surg 2017: 477-478

ORIGINAL SUBMISSION: Aortic Root Reconstruction and Valve Repair During Acute Type A Aortic Dissection Repair. Jared P. Beller. Oper Tech Thorac Cardiovasc 2017: 80-90

ORIGINAL SUBMISSION: Repair of the Bicuspid Aortic Valve. Ulrich Schneider. Oper Tech Thorac Cardiovasc 2017: 91-109 


\section{APPENDIX E1. METHODS Surgical Details}

Patients who underwent aortic valve replacement with cryopreserved aortic allograft had at least 1 among the following inclusion criteria: age younger than 40 years $(n=125)$, woman of childbearing age $(n=44)$, contraindication to oral anticoagulation $(\mathrm{n}=86)$ related to poor compliance to treatment, personal preference, childbearing age or bleeding disorders, and endocarditis $(\mathrm{n}=118)$. The technical details of aortic allograft insertion have been widely described. ${ }^{\mathrm{E} 1}$ In the free-hand subcoronary implantation technique, the allograft was scalloped, and only the valve tissue and the annulus were grafted with a proximal interrupted suture line on the annulus and a distal running suture line on the ascending aorta. In the root replacement with coronary reimplantation, also known as the miniroot technique, the entire complex constituted by the aortic valve, and sinuses of Valsalva were transplanted. The proximal anastomosis on the annulus was initially achieved with interrupted sutures, then the allograft was positioned at the level of coronary ostia and secured with knots. Subsequently, the coronary arteries were reimplanted in situ and the distal anastomosis with the ascending aorta completed with running sutures.

\section{Details on Clinical Follow-up}

Periodical data collection was performed at discharge, at 6 months, and on a yearly basis. In addition, because of the different regional provenances of the patients, cross-sectional analysis in a retrospective manner was carried out over the first semester of the year 2016. Clinical examination in outpatient clinic or phone interview were used to obtain data for the clinical follow-up. Complete clinical examinations from the referring cardiologists or general practitioners were also accepted. Systematic follow-up information was obtained at 1 years, 5 years, and 5-year intervals for 20 years, with patient consent at each contact. Noninvasive imaging was associated with outpatient visit, or a telephonic interview with 1 of the patient's relatives in case of adverse events. All indications for aortic allograft reoperation were in conformity with the American College of Cardiology/American Heart Association guidelines.

\section{Echocardiographic Follow-up}

Echocardiograms were obtained routinely before discharge and then every year to measure postoperative aortic valve (AV) configuration and hemodynamic stability. (AV mean and peak gradients $[\mathrm{mm} \mathrm{Hg}], \mathrm{AV}$ regurgitation grade, transvalvular gradients and effective valve orifice areas [EOAs], left ventricular end-diastolic diameter, aortic annular diameter, left ventricular outflow tract diameter, ascending aorta dimension, and left ventricular function). The EOA was indexed to the patient's body surface area. Homograft-patient mismatch was defined as an indexed $\mathrm{EOA} \leq 0.73 \mathrm{~cm}^{2} / \mathrm{m}^{2}$.

\section{E-Reference}

E1. O'Brien MF, McGiffin DC, Stafford EG. Allograft aortic valve implantation: techniques for all types of aortic valve and root pathology. Ann Thorac Surg. 1989:48:600-9. 
TABLE E1. Echocardiographic results and NYHA class changes

\begin{tabular}{|c|c|c|c|c|c|c|c|}
\hline & $\begin{array}{c}\text { Preoperative, } \\
\mathbf{N}=\mathbf{2 1 0}\end{array}$ & $\begin{array}{l}\text { After } 1 y, \\
N=198\end{array}$ & $\begin{array}{l}\text { After } 5 y, \\
N=193\end{array}$ & $\begin{array}{c}\text { After } 10 y, \\
N=154\end{array}$ & $\begin{array}{c}\text { After } 15 y \\
\quad N=82\end{array}$ & 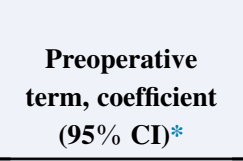 & $\begin{array}{c}\text { Time } \\
\text { term }(\mathbf{m o}), \\
\text { coefficient } \\
(\mathbf{9 5} \% \mathbf{C I}) * \\
\end{array}$ \\
\hline $\begin{array}{l}\text { LVEDD } \\
\text { Difference } \dagger \\
\quad P \text { value }\end{array}$ & $52.9 \pm 6.4$ & $\begin{array}{l}46.6 \pm 4.8 \\
-5.6 \pm 1.7 \\
\quad<.001\end{array}$ & $\begin{array}{l}45.7 \pm 4.6 \\
-0.9 \pm 1.2 \\
<.001\end{array}$ & $\begin{array}{c}45.8 \pm 4.7 \\
0.1 \pm 0.3 \\
.032\end{array}$ & $\begin{array}{c}46.3 \pm 4.7 \\
0.3 \pm 1.0 \\
.001\end{array}$ & $\begin{array}{c}0.911 \\
(0.90-0.92) \\
.001\end{array}$ & $\begin{array}{c}0.001 \\
(-0.002 \text { to } 0.004) \\
.514\end{array}$ \\
\hline $\begin{array}{l}\text { LVESD } \\
\qquad \text { Difference } \dagger \\
\quad P \text { value }\end{array}$ & $38.0 \pm 6.9$ & $\begin{array}{c}35.5 \pm 6.4 \\
-2.0 \pm 1.2 \\
<.001\end{array}$ & $\begin{array}{c}34.7 \pm 6.4 \\
-0.7 \pm 1.1 \\
<.001\end{array}$ & $\begin{array}{c}34.8 \pm 6.4 \\
0.1 \pm 0.2 \\
.052\end{array}$ & $\begin{array}{c}35.7 \pm 6.1 \\
0.2 \pm 0.9 \\
.005\end{array}$ & $\begin{array}{c}0.955 \\
(0.949-0.960) \\
.001\end{array}$ & $\begin{array}{c}0.005 \\
(0.003-0.007) \\
.001\end{array}$ \\
\hline $\begin{array}{l}\text { EF } \\
\quad \text { Difference } \dagger \\
\quad P \text { value }\end{array}$ & $51.8 \pm 8.1$ & $\begin{array}{c}57.8 \pm 5.7 \\
5.1 \pm 2.9 \\
<.001\end{array}$ & $\begin{array}{c}58.8 \pm 5.5 \\
1.0 \pm 1.7 \\
<.001\end{array}$ & $\begin{array}{c}58.8 \pm 5.5 \\
0.1 \pm 0.2 \\
.565\end{array}$ & $\begin{array}{c}58.0 \pm 5.8 \\
-0.3 \pm 1.3 \\
.007\end{array}$ & $\begin{array}{c}1.075 \\
(1.067-1.083) \\
.001\end{array}$ & $\begin{array}{c}-0.002 \\
(-0.005 \text { to } 0.002) \\
.326\end{array}$ \\
\hline $\begin{array}{l}\text { AV regurgitation grade } \\
\text { Difference } \dagger \\
P \text { value }\end{array}$ & $2.6 \pm 1.4$ & $\begin{array}{c}0.4 \pm 0.5 \\
-2.1 \pm 1.3 \\
<.001\end{array}$ & $\begin{array}{c}0.4 \pm 0.5 \\
0.1 \pm 0.1 \\
.318\end{array}$ & $\begin{array}{c}0.4 \pm 0.5 \\
0.1 \pm 0.2 \\
.416\end{array}$ & $\begin{array}{l}0.8 \pm 0.7 \\
0.4 \pm 0.7 \\
\quad<.001\end{array}$ & $\begin{array}{c}-0.072 \\
(-0.158 \text { to } 0.014) \\
.104\end{array}$ & $\begin{array}{c}0.008 \\
(0.006-0.011) \\
.001\end{array}$ \\
\hline $\begin{array}{l}\text { AV gradient } \\
\text { Difference } \dagger \\
P \text { value }\end{array}$ & $25.3 \pm 8.9$ & $\begin{array}{c}9.1 \pm 1.6 \\
-16.4 \pm 9.2 \\
\quad<.001\end{array}$ & $\begin{array}{c}9.1 \pm 1.6 \\
0.1 \pm 0.1 \\
.468\end{array}$ & $\begin{array}{c}9.2 \pm 1.6 \\
0.1 \pm 0.2 \\
.028\end{array}$ & $\begin{array}{l}9.9 \pm 2.0 \\
0.8 \pm 1.8 \\
<.001\end{array}$ & $\begin{array}{c}0.452 \\
(0.428-0.476) \\
.001\end{array}$ & $\begin{array}{c}0.035 \\
(0.027-0.043) \\
.001\end{array}$ \\
\hline $\begin{array}{l}\text { Annular diameter } \\
\text { Difference } \dagger \\
P \text { value }\end{array}$ & $22.1 \pm 1.8$ & $\begin{array}{c}22.3 \pm 1.8 \\
0.2 \pm 0.6 \\
<.001\end{array}$ & $\begin{array}{c}22.3 \pm 1.8 \\
0.1 \pm 0.3 \\
.493\end{array}$ & $\begin{array}{c}22.3 \pm 1.7 \\
0.1 \pm 0.1 \\
.018\end{array}$ & $\begin{array}{c}22.5 \pm 1.7 \\
0.1 \pm 0.3 \\
.013\end{array}$ & $\begin{array}{c}1.005 \\
(1.002-1.008) \\
.001\end{array}$ & $\begin{array}{c}0.002 \\
(0.002-0.003) \\
.001\end{array}$ \\
\hline $\begin{array}{l}\text { LVOT diameter } \\
\text { Difference } \dagger \\
P \text { value }\end{array}$ & $21.5 \pm 1.8$ & $\begin{array}{c}21.8 \pm 1.8 \\
0.3 \pm 0.7 \\
\quad<.001\end{array}$ & $\begin{array}{c}21.8 \pm 1.8 \\
0.1 \pm 0.1 \\
.318\end{array}$ & $\begin{array}{c}21.8 \pm 1.8 \\
0.1 \pm 0.1 \\
.318\end{array}$ & $\begin{array}{c}21.8 \pm 1.8 \\
0.1 \pm 0.1 \\
.319\end{array}$ & $\begin{array}{c}1.002 \\
(1.000-1.005) \\
.001\end{array}$ & $\begin{array}{c}0.001 \\
(0.001-0.002) \\
.001\end{array}$ \\
\hline $\begin{array}{l}\text { Aortic diameter } \\
\text { Difference } \dagger \\
P \text { value }\end{array}$ & $34.3 \pm 4.1$ & $\begin{array}{c}34.1 \pm 4.0 \\
0.1 \pm 0.5 \\
.286\end{array}$ & $\begin{array}{c}34.1 \pm 4.1 \\
0.1 \pm 0.6 \\
.870\end{array}$ & $\begin{array}{c}33.9 \pm 4.2 \\
-0.2 \pm 0.9 \\
.009\end{array}$ & $\begin{array}{c}33.9 \pm 4.7 \\
0.1 \pm 3.1 \\
.927\end{array}$ & $\begin{array}{c}-0.072 \\
(-0.158 \text { to } 0.015) \\
.104\end{array}$ & $\begin{array}{c}0.008 \\
(0.006-0.011) \\
.001\end{array}$ \\
\hline \multicolumn{8}{|l|}{ NYHA class } \\
\hline $\begin{array}{l}1 \\
2\end{array}$ & $\begin{array}{c}0(0.0 \%) \\
64(30.5 \%)\end{array}$ & $\begin{array}{c}144(72.7 \%) \\
51(25.7 \%)\end{array}$ & $\begin{array}{c}144(74.6 \%) \\
45(23.3 \%)\end{array}$ & $\begin{array}{l}97(63.0 \%) \\
51(33.1 \%)\end{array}$ & $\begin{array}{l}45(56.9 \%) \\
22(26.8 \%)\end{array}$ & -0.172 & 0.008 \\
\hline 3 & $86(40.9 \%)$ & $2(1.0 \%)$ & $3(1.5 \%)$ & $3(1.9 \%)$ & $9(10.9 \%)$ & $(-0.287$ to -0.144$)$ & $(0.006-0.011)$ \\
\hline 4 & $63(30.0 \%)$ & $1(0.5 \%)$ & $1(0.5 \%)$ & $3(1.9 \%)$ & $5(6.1 \%)$ & .001 & .001 \\
\hline
\end{tabular}

$C I$, Confidence interval; $L V E D D$, left ventricular end-diastolic diameter; $L V E S D$, left ventricular end-systolic diameter; $E F$, ejection fraction; $A V$, aortic valve; $L V O T$, left ventricular outflow tract; $N Y H A$, New York Heart Association. *Preoperative effect and time effect were evaluated with a longitudinal mixed-effect regression: the patient was considered a random effect; preoperative value and time from surgery to observation (in months) were considered fixed effects. Associated $P$ value is shown. $\dagger$ Difference is calculated from the previous time point using paired data, with associated $P$ value. 
TABLE E2. Clinical outcomes classified by etiology and surgical procedure

\begin{tabular}{|c|c|c|}
\hline Outcome & Patients & $P$ value \\
\hline Early mortality & 12 & \\
\hline \multicolumn{3}{|l|}{ By etiology } \\
\hline Endocarditis & 9 & .165 \\
\hline Rheumatic & 3 & \\
\hline Congenital & 0 & \\
\hline Other & 0 & \\
\hline By technical procedure & & 147 \\
\hline Freehand & 1 & \\
\hline Miniroot & 11 & \\
\hline Overall mortality & 80 & \\
\hline \multicolumn{3}{|l|}{ By etiology } \\
\hline Endocarditis & 23 & \\
\hline Rheumatic & 23 & $<.001$ \\
\hline Congenital & 19 & \\
\hline Other & 11 & \\
\hline By technical procedure & & .004 \\
\hline Freehand & 12 & \\
\hline Miniroot & 68 & \\
\hline Valve-related cardiac late mortality & 36 & \\
\hline By etiology & & .909 \\
\hline Endocarditis & 20 & \\
\hline Rheumatic & 8 & \\
\hline Congenital & 6 & \\
\hline Other & 2 & \\
\hline By technical procedure & & 689 \\
\hline Freehand & 8 & \\
\hline Miniroot & 18 & \\
\hline Not valve-related late mortality & 22 & \\
\hline Not cardiac mortality & 10 & \\
\hline Reoperation & 69 & \\
\hline \multicolumn{3}{|l|}{ By etiology } \\
\hline Endocarditis & 35 & .272 \\
\hline Rheumatic & 19 & \\
\hline Congenital & 9 & \\
\hline Other & 6 & \\
\hline By technical procedure & & $<.001$ \\
\hline Freehand & 32 & \\
\hline Miniroot & 37 & \\
\hline Reoperation for SVD & 57 & \\
\hline \multicolumn{3}{|l|}{ By etiology } \\
\hline Endocarditis & 30 & .601 \\
\hline Rheumatic & 15 & \\
\hline Congenital & 7 & \\
\hline Other & 5 & \\
\hline By technical procedure & & $<.001$ \\
\hline Freehand & 30 & \\
\hline Miniroot & 27 & \\
\hline
\end{tabular}

TABLE E2. Continued

\begin{tabular}{lcc}
\hline \multicolumn{1}{c}{ Outcome } & Patients & $\boldsymbol{P}$ value \\
\hline MACCEs & 115 & \\
By etiology & & \\
Endocarditis & 51 & \\
Rheumatic & 31 & .914 \\
Congenital & 21 & \\
Other & 12 & \\
By technical procedure & & .124 \\
Freehand & 36 & \\
Miniroot & 79 & \\
\hline
\end{tabular}

$\overline{S V D}$, Structural valve degeneration; MACCE, major adverse cardiac and cerebrovascular event.
TABLE E3. Characteristics of tear and wear

\begin{tabular}{lc}
\hline Characteristics of tear and wear & Patients with SVD $(\mathbf{N}=\mathbf{6 9})$ \\
\hline Right cusp & 26 \\
With calcifications & 5 \\
Left cusp & 24 \\
With calcifications & 10 \\
Right and left cusp & 19 \\
With calcifications & 13 \\
\hline SVD, Structural valve degeneration. &
\end{tabular}


TABLE E4. Clinical outcomes in childbearing age

\begin{tabular}{|c|c|c|c|}
\hline Outcomes & $\begin{array}{c}\text { Women in childbearing age } \\
\text { who had children }\end{array}$ & $\begin{array}{l}\text { Women childbearing age } \\
\text { who did not have children }\end{array}$ & $P$ value \\
\hline Number of patients & 37 & 7 & \\
\hline Overall death & 17 & 5 & .216 \\
\hline Valve-related cardiac death & 4 & 0 & .362 \\
\hline Structural valve degeneration & 9 & 2 & .812 \\
\hline Reoperation & 10 & 2 & .933 \\
\hline MACCEs & 20 & 5 & .395 \\
\hline Outcomes & $\begin{array}{l}\text { Women in childbearing age } \\
\text { who delivered after surgery }\end{array}$ & All ages women & $P$ value \\
\hline Number of patients & 37 & 48 & \\
\hline Valve-related cardiac death & 4 & 7 & .607 \\
\hline Structural valve degeneration & 9 & 5 & .087 \\
\hline Reoperation & 10 & 9 & .364 \\
\hline MACCEs & 20 & 19 & .184 \\
\hline
\end{tabular}

MACCE, Major adverse cardiac and cerebrovascular event. 
TABLE E5. Multivariable Cox regression: overall mortality, cardiac-related mortality, MACCEs, and reoperation

\begin{tabular}{|c|c|c|c|c|}
\hline Overall mortality & Hazard ratio & $95 \%$ CI & $P$ value & $\begin{array}{c}\text { Test of proportional hazard assumption } \\
\text { Overall model, } P=.232\end{array}$ \\
\hline Male sex & 0.94 & $0.43-2.07$ & .889 & .724 \\
\hline Age & 1.07 & 1.04-1.09 & .001 & .058 \\
\hline \multicolumn{5}{|l|}{ Etiology (ref. endocarditis) } \\
\hline Rheumatic & 0.77 & $0.17-3.48$ & .740 & .761 \\
\hline Congenital & 1.73 & $0.50-5.96$ & .382 & .443 \\
\hline Degenerative & 1.32 & $0.55-3.18$ & .524 & .683 \\
\hline Freehand technique & 0.61 & $0.24-1.57$ & .312 & .976 \\
\hline Valve size & 0.86 & $0.72-1.02$ & .096 & .243 \\
\hline Preoperative ejection fraction & 0.97 & $0.93-1.01$ & .198 & .071 \\
\hline Cardiac mortality & Hazard ratio & $95 \% \mathrm{CI}$ & $P$ value & $\begin{array}{c}\text { Test of proportional hazard assumption } \\
\text { Overall model, } P=.062\end{array}$ \\
\hline Male sex & 0.94 & $0.39-2.24$ & .892 & .886 \\
\hline Age & 1.06 & 1.03-1.09 & .001 & .052 \\
\hline \multicolumn{5}{|l|}{ Etiology (ref. endocarditis) } \\
\hline Rheumatic & 0.70 & $0.14-3.34$ & .655 & .983 \\
\hline Congenital & 1.27 & $0.30-5.31$ & .739 & .231 \\
\hline Degenerative & 0.72 & $0.21-2.44$ & .597 & .829 \\
\hline Freehand technique & 0.94 & $0.35-2.51$ & .903 & .936 \\
\hline Valve size & 0.84 & $0.69-1.03$ & .104 & .078 \\
\hline Preoperative ejection fraction & 0.95 & 0.91-0.99 & .030 & .059 \\
\hline MACCEs & Hazard ratio & $\mathbf{9 5} \% \mathbf{C I}$ & $P$ value & $\begin{array}{c}\text { Test of proportional hazard assumption } \\
\text { Overall model, } P=.235\end{array}$ \\
\hline Male sex & 1.10 & $0.65-1.88$ & .704 & .897 \\
\hline Age & 1.00 & $0.98-1.01$ & .711 & .543 \\
\hline \multicolumn{5}{|l|}{ Etiology (ref. endocarditis) } \\
\hline Rheumatic & 0.98 & $0.46-2.05$ & .957 & .869 \\
\hline Congenital & 0.59 & $0.27-1.26$ & .175 & .611 \\
\hline Degenerative & 0.94 & $0.45-1.94$ & .868 & .351 \\
\hline Freehand technique & 0.72 & $0.39-1.31$ & .289 & .751 \\
\hline Valve size & 0.93 & $0.82-1.06$ & .300 & .444 \\
\hline Preoperative ejection fraction & 0.981 & $0.95-1.01$ & .295 & .053 \\
\hline
\end{tabular}

\begin{tabular}{lcccc}
\hline \multicolumn{1}{c}{ Reoperation } & Hazard ratio & $\mathbf{9 5 \%} \mathbf{C I}$ & $\boldsymbol{P}$ value & $\begin{array}{c}\text { Test of proportional hazard assumption } \\
\text { Overall model, } \boldsymbol{P}=\mathbf{. 7 6 8}\end{array}$ \\
\hline Male sex & 1.01 & $0.49-2.07$ & .971 & .233 \\
Age & 1.00 & $0.98-1.02$ & .729 & .263 \\
Etiology (ref. endocarditis) & & & & .506 \\
$\quad$ Rheumatic & 1.81 & $0.64-5.08$ & .257 & .895 \\
$\quad$ Congenital & 0.88 & $0.33-2.33$ & .799 & .925 \\
$\quad 1.33$ & $0.49-3.62$ & .565 & .555 \\
Degenerative & 0.63 & $0.28-1.39$ & .259 & $\mathbf{. 3 4 2}$ \\
Vreehand technique & $\mathbf{0 . 7 9}$ & $\mathbf{0 . 6 7 - 0 . 9 5}$ & .012 & .585 \\
\hline Preoperative ejection fraction & 0.96 & $0.91-1.01$ & .076 & \\
\hline
\end{tabular}

Bold indicates statistical significance. $C I$, Confidence interval; $M A C C E$, major adverse cardiac and cerebrovascular events. 
TABLE E6. Effect of freehand/subcoronary implantation technique: Longitudinal analysis of echocardiographic data

\begin{tabular}{|c|c|c|c|c|c|c|c|}
\hline Variable & Coefficient & $95 \%$ CI & $P$ value & Sigma_u & Sigma_e & Rho & Sigma2_u $(95 \%$ CI $)$ \\
\hline LVEDD & -2.20 & -3.71 to -0.70 & .004 & 4.61 & 3.40 & 0.65 & \\
\hline LVESD & -2.14 & -4.11 to -0.17 & .033 & 6.28 & 2.11 & 0.89 & \\
\hline LVEF & 2.99 & $1.15-4.83$ & .001 & 5.68 & 3.76 & 0.69 & \\
\hline Aortic valve gradient & 2.29 & $1.15-3.43$ & .001 & 0.00 & 9.22 & 0.00 & \\
\hline Annular diameter & 0.33 & -0.19 to 0.86 & .218 & 1.70 & 0.46 & 0.93 & \\
\hline LVOT diameter & 0.35 & -0.18 to 0.88 & .198 & 1.71 & 0.43 & 0.94 & \\
\hline Aortic diameter & -0.64 & -1.86 to 0.58 & .306 & 3.88 & 1.59 & 0.85 & \\
\hline Aortic regurgitation grade & 0.17 & -0.15 to 0.49 & .297 & & & & $0.43(0.24-0.76)$ \\
\hline NYHA class & -1.01 & -1.41 to -0.61 & .001 & & & & $0.72(0.46-1.12)$ \\
\hline
\end{tabular}

Bold indicates statistical significance. $C I$, Confidence interval; $L V E D D$, left ventricular end-diastolic diameter; $L V E S D$, left ventricular end-systolic diameter; $L V E F$, left ventricular ejection fraction; LVOT, left ventricular outflow tract; NYHA, New York Heart Association. 